\title{
Adopting global guidelines for air pollution: protecting the health of Canadians
}

\author{
Moneeza Walji MD MPH, Ken Flegel MDCM MSc
}

$\mathrm{I}$ n 2014, the World Health Organization (WHO) called air pollution the world's single largest environmental health risk. Pollution is linked to one in eight deaths worldwide. ${ }^{1}$ In May 2015, the World Health Assembly delivered the first resolution on air pollution, urging member states to take serious action to curb global levels of pollutants by developing air-quality monitoring systems and mechanisms to track illnesses caused by air pollution. ${ }^{1}$ Many Canadians may not consider the large burden that air pollution places on our health. In 2008, it was estimated that more than 20000 premature deaths related to outdoor air pollution occur each year in Canada. ${ }^{2}$ Yet, current Canadian standards for air pollutant levels ${ }^{3}$ lag behind WHO guidelines. ${ }^{4}$

What pollutes our air? A mix of fine particulates and gases are generated from natural and man-made sources. Fine particulates are formed from the burning of fossil fuels and wood, from dust from paved and unpaved roads, and from construction sources. The smaller the particulate, the more harmful it is to health; particulates of less than $2.5 \mu \mathrm{m}$ in diameter $\left(\mathrm{PM}_{2.5}\right)$ are considered to be the most harmful. Other substances classified as air pollutants include nitrogen oxides (from transportation and industrial emissions), volatile organic compounds (largely from industrial emissions) and ground-level ozone (formed by the interaction of sunlight with volatile organic compounds and nitrogen oxides).

Children are especially vulnerable to air pollution. A large cohort study in southern California found that increased concentrations of pollutants, particularly nitrogen dioxide and $\mathrm{PM}_{2.5}$, resulted in adverse effects on lung development in children that persisted as they reached adulthood. ${ }^{5}$ This is important because reduction in lung function in adults is a strong risk factor for respiratory and cardiovascular illnesses. Following the improvement in air quality in the same region of California, more than 2000 children had their lung function measured. The observed decreases in levels of nitrogen dioxide and fine particulates were associated with improvements in lung function. ${ }^{6}$

Air pollution also has short- and long-term harmful effects on the health of adults. ${ }^{7}$ Higher concentrations of pollutants have been associated with increased risks of hospital admission for respiratory and cardiovascular diseases and mortality, ${ }^{8}$ as well as an increased risk of Alzheimer disease. ${ }^{9}$

The recently revised Canadian air-quality standards ${ }^{3}$ do not meet WHO guidelines. ${ }^{4}$ The Canadian standard for the peak 24-hour concentration of $\mathrm{PM}_{2.5}$ is $28 \mu \mathrm{g} / \mathrm{m}^{3}$; WHO recommends $25 \mu \mathrm{g} / \mathrm{m}^{3}$. The Canadian standard for ground-level ozone is 65 parts per billion, $15 \mathrm{ppb}$ above the WHO guideline. Even at the recommended WHO level, ozone can have substantial health effects, with an estimated increase in mortality of $1 \%-2 \% .^{4}$

Although air pollution is a global problem, pollutant levels vary geographically. In 2012, the annual peak 24-hour concentration of $\mathrm{PM}_{2.5}$ was $18.8 \mu \mathrm{g} / \mathrm{m}^{3}$ nationally, but $26.7 \mu \mathrm{g} / \mathrm{m}^{3}$ in southern Quebec. ${ }^{10}$ That same year, the average ozone concentration was 60.6 ppb nationally, but 76.3 ppb in southern Ontario. ${ }^{10}$

Man-made sources of air pollution in Canada are diverse, including wood-burning stoves, and the oil and gas industry. Mobile sources, such as diesel-powered vehicles, contribute more than half of nitrogen oxide emissions. ${ }^{11}$ About 10 million Canadians live near major highways and intersections and are exposed to traffic-related air pollution. ${ }^{2}$ Schools close to highways and diesel-powered school buses expose our children to pollutants.

To address this health issue, Canada must adopt and enforce the WHO guidelines in all jurisdictions and improve monitoring of our air quality. Best practices for reducing pollution should be shared across jurisdictions and take into account local sources of pollutants. While national strategies catch up, we should also consider the harmful impact of air pollution as we drive our cars, heat and cool our homes, and head to the ballot box.

\section{References}

1. World Health Organization. Health and the environment: addressing the health impact of air pollution [resolution WHA68.8]. Sixty-eighth World Health Assembly; 2015 May 26. Available: http://apps.who.int/gb/ebwha/pdf_files/WHA68/ A68_R8-en.pdf?ua=1 (accessed 2015 June 29).

2. Brauer M, Reynolds C, Hystad P. Traffic-related air pollution and health in Canada. CMAJ 2013; 185:1557-8.

3. Canadian Ambient Air Quality Standards (CAAQS). Winnipeg: Canadian Council of Ministers of the Environment; 2014. Available: www.ccme.ca/en/current_priorities/ air/caaqs.html (accessed 2015 June 29).

4. WHO air quality guidelines for particulate matter, ozone, nitrogen dioxide and sulfur dioxide: global update 2005. Geneva: World Health Organization; 2006. Available: http://whqlibdoc.who.int/hq/2006/WHO_SDE_PHE_OEH_06.02_eng.pdf?ua=1 (accessed 2015 June 29).

5. Gauderman WJ, Avol E, Gilliland F, et al. The effect of air pollution on lung development from 10 to 18 years of age. N Engl J Med 2004;351:1057-67.

6. Gauderman WJ, Urman R, Avol E, et al. Association of improved air quality with lung development in children. N Engl J Med 2015;372:905-13.

7. Anderson JO, Thundiyil J, Strolbach A. Clearing the air: a review of the effects of particulate matter air pollution on human health. J Med Toxicol 2012;8:166-75.

8. Atkinson RW, Kang S, Anderson HR, et al. Epidemiological time series studies of $\mathrm{PM}_{25}$ and daily mortality and hospital admissions: a systematic review and metaanalysis. Thorax 2014;69:660-5.

9. Jung CR, Lin YT, Hwang BF. Ozone, particulate matter, and newly diagnosed Alzheimer's disease: a population-based cohort study in Taiwan. J Alzheimers Dis 2015;44:573-84.

10. Air quality indicators. Ottawa: Environment Canada; 2015. Available: http://ec.gc.ca/ indicateurs-indicators/default.asp?lang=En\&n=7DCC2250-1 (accessed 2015 June 29).

11. Air Pollutant Emission Inventory (APEI) report. Ottawa: Environment Canada; 2015 Available: www.ec.gc.ca/pollution/default.asp?lang=En\&n=89ED82E9-1\&offset=7 \&toc $=$ show (accessed 2015 June 29).

Competing interests: See www.cmaj.ca/site/misc/cmaj_staff.xhtml

Affiliations: Editorial Fellow (Walji) and Senior Editor (Flegel), CMAJ

Correspondence to: $C M A J$ editor, pubs@cmaj.ca

CMAJ 2015. DOI:10.1503/cmaj.150722

All editorial matter in CMAJ represents the opinions of the authors and not necessarily those of the Canadian Medical Association. 